\title{
Peningkatan Kompetensi Guru Bina Insani dalam Membuat Visualisasi Bahan Ajar
}

\section{Increasing the Competence of Bina Insani Teachers in Making Visualization of Teaching Materials}

\author{
Sugiyanto $^{* 1}$, Edi Faisal ${ }^{2}$, Liya Umaroh ${ }^{3}$ \\ 1,2,3 Fakultas Ilmu Komputer Universitas Dian Nuswantoro, Jl. Imam Bonjol 207 \\ Semarang,(024)-3517261

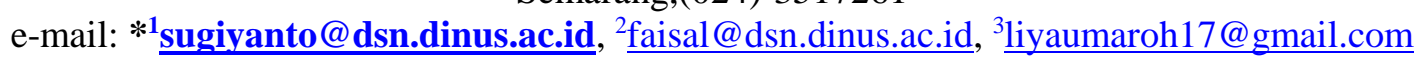

\begin{abstract}
Abstrak
Banyak sekolah masih menggunakan bahan ajar konvensional dan belum memiliki bahan ajar pendamping sebagai pendukung siswa untuk lebih mudah dalam memahami materi pelajaran yang berupa Visualisasi Materi Pelajaran menggunakan animasi. Visualisasi materi pelajaran dapat memberikan pengetahuan yang lebih dibandingkan dengan menggunakan narasi atau gambar statis. Metode Kualitatif digunakan untuk menjelaskan Kegiatan Pelatihan Pembuatan Visualisasi Bahan Ajar pada SDIT Bina Insani. Kegiatan pelatihan ini merupakan solusi bagi permasalahan kurangnya kemampuan membuat visualisasi bahan ajar pada SDIT Bina Insani. Pelaksanaan diskusi hasil pelatihan pembuatan visualisasi bahan ajar dilaksanakan dengan agenda setiap guru harus mempresentasikan karyanya. Dari karya karya yang dihasilkan dapat dikelompokkan dalam 3 (tiga) kelompok karya yaitu: Kelompok I baru dapat menerapkan penggunaan teknik-teknik animasi, Kelompok II mampu membuat desain karakter dan kelompok III mampu menerapkan teknik animasi pada obyek yang akan digunakan pada visualisasi dan penggunaan audio.
\end{abstract}

Kata kunci - Visualisasi, Animasi, Bahan Ajar, Materi Pelajaran

\begin{abstract}
Many schools have used conventional teaching materials and most of them did not have companion teaching materials for supporting students in order to make them easily understand the subject in the form of Visualization of Learning Materials using animation. Visualization can provide more knowledge than using static narratives or images. The Qualitative Method is used to explain the Activity of Teaching Material Visualization Training at SDIT Bina Insani. This training activity is a solution to the problem because of the lack ability to make visualization in teaching materials at SDIT Bina Insani. The discussion on the results of the training in making visualization and teaching materials was carried out with the agenda of each teacher to present his work. From the work produced can be grouped in 3 (three) groups of work, namely: Group I can only apply the use of animation techniques, Group II is able to design characters and group III is able to apply animation techniques to objects that will be used in visualization and use of audio.
\end{abstract}

Keywords - Visualization, Animation, Teaching Materials, Subject Matter 


\section{PENDAHULUAN}

Model pembelajaran konvensional di sekolah-sekolah saat ini masih banyak yang menggunakan buku-buku paket atau Lembar Kerja Siswa. Tetapi masih belum banyak sekolah yang memiliki bahan ajar pendamping sebagai pendukung siswa untuk lebih mudah dalam memahami materi pelajaran. Misalnya : Model Pembelajaran Interaktif, Pembelajaran Multimedia, atau Visualisasi Materi Pelajaran. Menurut Dikmenjur, Bahan ajar merupakan seperangkat materi/substansi pembelajaran (teaching material) yang disusun secara sistematis, menampilkan sosok utuh dari kompetensi yang akan dikuasai siswa dalam kegiatan pembelajaran [1]. Peran bahan ajar dalam pembelajaran adalah untuk penyajian bahan belajar, sumber kegiatan bagi siswa untuk berlatih berkomunikasi secara interaktif, rujukan informasi kebahasaan, sumber stimulan, gagasan suatu kegiatan kelas, silabus, dan bantuan bagi guru yang kurang berpengalaman untuk menumbuhkan keparcayaan diri (Cunningsworth, $1995:$ 7) [2].

Penulisan bahan ajar bermanfaat untuk: (1) membantu guru dalam proses pembelajaran; (2) memudahkan penyajian materi di kelas; (3) membimbing siswa belajar dalam waktu yang lebih banyak; (4) siswa tidak tergantung kepada guru sebagai satu-satunya sumber informasi; dan (5) dapat menumbuhkan motivasi siswa untuk mengembangkan diri dalam mencerna dan memahami pelajaran [1]. Menurut Aqib (2014: 50), media pembelajaran adalah segala sesuatu yang dapat digunakan untuk menyalurkan pesan dan merangsang terjadinya proses belajar pada si pembelajar (siswa) [3].

Sekolah Islam Terpadu Bina Insani hadir untuk membentuk peserta didik menjadi anak - anak yang memiliki konsep diri yang matang, motivasi yang kuat, daya Intelektual yang tinggi, tangguh, produktif dan mampu bersosialisasi dengan baik. hal ini perlu didukung dengan fasilitas bahan ajar yang mampu memberikan dukungan kepada siswa dalam memahami materi pelajaran dengan pemahaman lebih baik.

Visualisasi materi pelajaran dapat memberikan pengetahuan yang lebih dibandingkan dengan menggunakan narasi atau gambar statis. Sakti (2013) menyatakan bahwa visualisasi dapat memperjelas pengamatan siswa dan memberikan kontribusi dalam peningkatan pemahaman siswa [4]. Dengan menggunakan visualisasi materi pelajaran, siswa diharapkan dapat menerima isi materi pelajaran dengan lebih menarik, lebih mudah dan lebih baik dalam mengingat materi pelajaran.

Dari analisa situasi tersebut, pengusul bersama mitra mengidentifikasi permasalahanpermasalahan yang dihadapi oleh mitra, terkait dengan bagaimana mitra bisa membuat visualisasi materi pelajaran dan mampu meningkatkan pemahaman siswa terhadap materi pelajaran menjadi lebih baik.

Adapun permasalahan-permasalahan yang menjadi prioritas dari hasil identifikasi yang telah dilakukan adalah visualisasi bahan ajar yang digunakan masih sedikit danbelum adanya guru yang mampu membuat visualisasi bahan ajar sendiri.

Dengan peningkatan kemampuan guru membuat visualisasi bahan ajar diharapkan guru dapat membuat bahan ajar sendiri dengan visualisasi yang lebih menarik, mudah dimengerti oleh siswa dan tentunya dapat meningkatkan hasil belajar siswa menjadi lebih baik lagi.

\section{METODE PENELITIAN}

Metode Kualitatif digunakan untuk menjelaskan Kegiatan Pelatihan Pembuatan Visualisasi Bahan Ajar pada SDIT Bina Insani. Kegiatan pelatihan ini merupakan solusi bagi permasalahan kurangnya kemampuan membuat visualisasi bahan ajar pada SDIT Bina Insani. Adapun pelaksanaan kegiatan ini meliputi tahapan tahapan :

1. Survey Mitra

2. Persiapan Kebutuhan Pelatihan

3. Pelaksanaan Kegiatan, yang meliputi : 

a. Pelatihan
b. Pendampingan/Konsultasi Proyek Visualisasi
c. Diskusi Hasil Pelatihan Pembuatan Visualisasi Bahan Ajar

4. Evaluasi

\section{HASIL DAN PEMBAHASAN}

\subsection{Survey Mitra}

Mitra dari kegiatan Program Kemitraan Masyarakat tentang Peningkatan Kompetensi Guru Bina Insani dalam Membuat Visualisasi Bahan Ajar Sesuai Materi Pelajaran ini adalah Sekolah Dasar Islam Terpadu Bina Insani Semarang. Dari hasil diskusi yang telah dilakukan, disepakati tentang beberapa hal : peserta, materi, tempat pelaksanaan, pola pelaksanaan, jadwal pelaksanaan, dan evaluasi hasil pelatihan.

\subsection{Persiapan Kebutuhan Pelatihan}

Sesuai hasil survey dan koordinasi awal, tim pelaksana Program Kemitraan Masyarakat mempersiapkan materi pelatihan, aplikasi yang dibutuhan dan instalasi aplikasi pada komputer yang akan digunakan untuk pelatihan. Materi yang diberikan adalah tentang pengenalan animasi, pembuatan animasi, hingga ekspor file proyek animasi kedalam format file movie (.mpeg).

\subsection{Pelaksanaan Kegiatan}

\section{a. Pelatihan}

Pelaksanaan kegiatan ini dilakukan dengan tahapan sebagai berikut :

Pelatihan tentang pembuatan visualisasi bahan ajar sesuai dengan materi pelajaran yang diampu oleh masing-masing guru dilaksanakan pada tanggal 24 November 2018 bertempat di Laboratorium Komputer Sekolah Dasar Islam Terpadu Bina Insani. Pada pelatihan ini, materi disampaikan tentang Pengenalan Animasi, Pembuatan Animasi dengan teknik Tweening Motion maupun Frame by Frame.

b. Pendampingan/Konsultasi Proyek Visualisasi

Pada kegiatan pendampingan ini, tim memberikan masukan kepada peserta terkait dengan proyek pembuatan visualisasi bahan ajar. Kendala-kendala yang dihadapi peserta didiskusikan dan diberikan solusi untuk kendala tersebut.

Pada kegiatan ini juga ditambahkan materi-materi yang sesuai dengan proyek visualisasi bahan ajar masing-masing guru. Misalnya : penggunaan audio dan sinkronisasi dalam animasi visualiasasi, animasi path untuk menggerakkan movieclip, hingga ekspor proyek animasi ke format file movie (.mpeg).

c. Hasil Pelatihan Pembuatan Visualisasi Bahan Ajar

Pelaksanaan diskusi hasil pelatihan pembuatan visualisasi bahan ajar ini dilaksanakan pada tanggal 30 Maret 2019 dengan agenda setiap guru harus mempresentasikan karyanya. Dari 18 peserta pelatihan, sebanyak 11 peserta menyerahkan hasil pelatihan dimana karya-karya tersebut dapat dikelompokkan menjadi 3 (tiga) kelompok karya, yaitu :

1) Kelompok I, latihan tentang penggunaan teknik-teknik animasi dengan contoh hasil sebagai berikut :

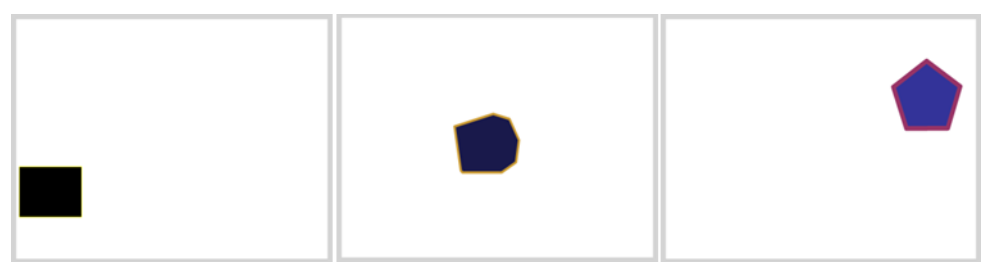


2) Kelompok II, pembuatan desain karakter dengan contoh hasil sebagai berikut :

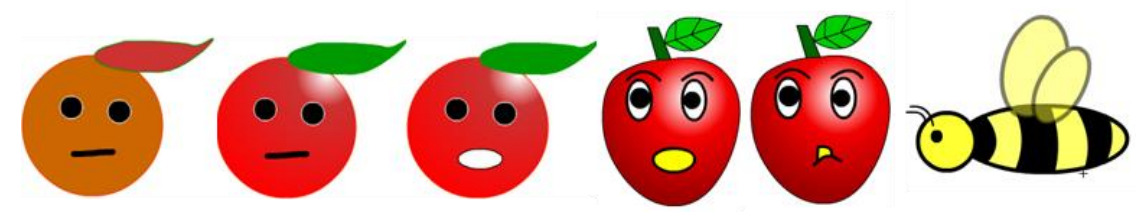

3) Kelompok III, sudah menerapkan teknik animasi pada obyek yang akan digunakan pada visualisasi dan penggunaan audio. Berikut contoh hasil dari kelompok III :

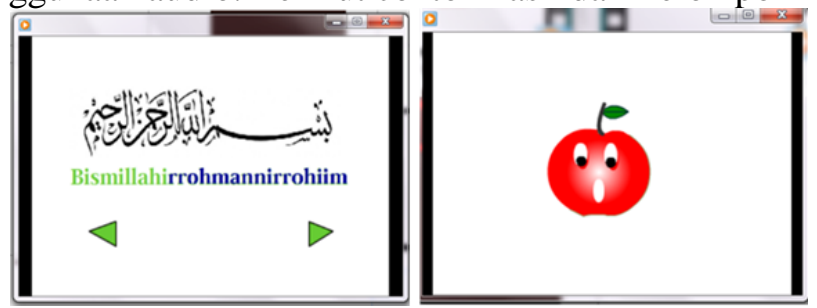

3.4. Evaluasi

Hasil pembuatan visualisasi materi oleh para guru, belum sesuai dengan harapan seperti yang disampaikan pada saat koordinasi dengan pihak sekolah. Beberapa alasan yang disampaikan oleh para guru antara lain :

1. Pelatihan dan pendampingan yang sudah dilakukan sebanyak 3 kali pertemuan, belum cukup untuk bisa membuat visualisasi materi pelajaran secara mandiri.

2. Banyaknya kegiatan sekolah diluar Proses Belajar Mengajar yang harus diikuti para guru.

3. Kegiatan pelatihan dan pendampingan yang dilaksanakan saat berlangsungnya masa Proses Belajar Mengajar kurang tepat.

\section{KESIMPULAN}

Pelaksanaan Program Kemitraan Masyarakat Peningkatan Kompetensi Guru Bina Insani dalam Membuat Visualisasi Bahan Ajar Sesuai Materi Pelajaran ini berjalan dengan baik atas partisipasi dan kerjasama antara tim pelaksana dari Universitas Dian Nuswantoro dan SDIT Bina Insani sebagai Mitra. Ada beberapa hal yang menjadi kendala dalam pelaksanaan kegiatan ini, antara lain :

1. Kurangnya tingkat ketrampilan guru dalam menggunakan aplikasi yang dipakai dalam pembuatan visualisasi media ajar karena waktu pelatihan yang hanya sehari dirasa kurang.

2. Pada saat kegiatan Program Kemitraan Masyarakat ini dilaksanakan, beban kegiatan guru sedang tinggi karena dilaksanakan pada periode pelaksanaan Proses Belajar Mengajar.

3. Pengaturan jadwal yang tidak sesuai, karena guru memiliki agenda kegiatan lain yang bersamaan dengan kegiatan pendampingan. Sehingga mengurangi konsentrasi guru dalam menyelesaikan tugas membuat visualisasi bahan ajar.

\section{SARAN}

Dari beberapa hal yang dapat disimpulkan dari pelaksanaan Program Kemitraan Masyarakat Peningkatan Kompetensi Guru Bina Insani dalam Membuat Visualisasi Bahan Ajar Sesuai Materi Pelajaran ini, untuk mendapatkan hasil maksimal sesuai target yang diharapkan, tim memberikan saran :

1. Guru mempersiapkan materi yang akan dibuatkan visualisasinya dengan baik. Hal ini bisa dilakukan dengan membuat gambar sket tentang obyek yang akan dibuat visualisasi. 
2. Guru meningkatkan kemampuan dalam menggunakan aplikasi untuk membuat animasi dengan sering berlatih membuat animas-animasi kecil yang tekniknya sudah diajarkan.

3. Pelaksanaan pelatihan dijadwalkan pada saat libur Proses Belajar Mengajar, sehingga pelaksanaan pelatihan bisa dilaksanakan dalam waktu yang berurutan.

\section{UCAPAN TERIMA KASIH}

Penulis mengucapkan terima kasih kepada Lembaga Penelitian dan Pengabdian Masyarakat (LPPM) Universitas Dian Nuswantoro yang telah memberikan dukungan melalui pendanaan serta kepada SDIT Bina Insani Semarang sebagai mitra dalam kegiatan pengabdian ini.

\section{DAFTAR PUSTAKA}

[1] Website, http://www.dikmenum.go.id

[2] Cunningsworth, A., 1995, Choosing Your Course Book. Oxford: Heinemann

[3] Aqib, Z., 2014, Model-Model, Media, dan Strategi Pembelajaran Kontekstual Inovatif, Bandung: Yrama Widya.

[4] Sakti, I., 2013, Pengaruh Media Animasi Fisika Dalam Model Pembelajaran Langsung (direct instruction) Terhadap Minat Belajar dan Pemahaman Konsep Fisika Siswa di SMA Negeri Kota Bengkulu, Prosiding SEMIRATA 2013, Vol. 1 (1), 64-65. 